\title{
The Process of Change from Chairs to Departments at Spanish Universities
}

\author{
Sara González Gómez“® \\ Department of Pedagogy and Specific Didactics, University of the Balearic Islands, Spain \\ \{sara.gonzalez@uib.es\} \\ Received on 15 October 2018; revised on 18 October 2018; accepted on 28 November 2018; published on 15 January 2019
}

DOI: $10.7821 /$ naer.2019.1.364

(c) BY-NC-ND

\begin{abstract}
The transformation of the model of university organization, with the passage of the traditional system of chairs to departmental, began in Spain in the mid-sixties. The educational policy of the regime, taking as reference foreign models such as the German or AngloSaxon, introduces via regulations, which are not real and operative, the bases of the new model through the Law of July 17, 1965 on the structure of university faculties and their teaching staff. This article analyses and discusses that initial process of gestation and insertion of the department as a new structure of the hierarchical-administrative organization of the institution, taking the University of Salamanca as an excellent illustration of this case study. For this, the historical method and unpublished printed sources are used minutes of the Council of Rectors, of Faculty Meetings, correspondence, etc. - as well as legislative sources, which provide us with the basic normative frame of reference. All this allows us to review the main legal milestones and some of the most relevant events that take place prior and subsequent approval of the departmental system, issues that will reveal motivations, points of view and tensions generated among the body of professors before the loss of chairs turned into authentic bastions.
\end{abstract}

KEYWORDS: UNIVERSITY, FRANCOISM, SPAIN, DEPARTMENT, CHAIR.

\section{INTRODUCTION}

The Spanish university of the sixties, still under the asphyxiating coordinates of an ineffective educational model, underwent a series of transformations - expansion of sections, appearance of new teaching categories, promotion of the exclusive dedication of the teaching staff, etc. - that, without being decisive at that time, did clarify some aspects of the outdated institution of the regime. Those initiatives began to mould, albeit slowly, a different university scene. Most of them were the result of the revision of some of the bases of the university organization and responded, in short, to the general Spanish environment, in which the concepts of effectiveness, efficiency, development and modernization acquired the leading role in the movements of higher echelons of the ministry who mainly acted as technocrats.

*To whom correspondence should be addressed: Univesitat de les Illes Balears. Edificio Guillem Cifre de Colonya. Cra. de Valldemossa, km. 7,5, 07122, Palma, Spain
The name "modern university" is closely linked to the concept of modernization that originates at an international level with the Humboldt University model. A research-oriented model focused on turning universities into fundamental instruments "in the process of strengthening the industrial and technological capabilities of the new nation-states, of providing competent administrative and technical personnel, and of serving as loci for the cultural discourses that will help to form the world of modernity, of industrialism and urbanism, intelligible and meaningful" (Wittrock, 1996, p. 355). The wave of international modernization of universities will extend throughout the 20th century, at different tempos in countries and continents, and will involve the introduction of important changes such as the link between research and teaching, generation of new pedagogical and curricular forms in accordance with the developments of the pedagogical and curricular theory or the increasing approximation to the closest environment (Malagón, 2005).

In the Spanish case, the University of the nineteenth century had been characterized by the scarcity of resources, the poor renovation of its studies and the allergy, when not open opposition, to rationalist currents and to modern science (Otero, 2006, p. 15). The conjunction of diverse factors made it possible that with the birth of the new century, in the year 1907, the Board for Extension of Studies and Scientific Investigations (JAE) arose. The policy carried out by the JAE was articulated through the promotion of basic science, the creation of infrastructures and institutions as platforms to advance in the generation of scientific knowledge; the establishment of instruments to harmonize education with scientific work and with the recognition, more or less explicit, of the importance of human capital for this task (Muñoz, 2001). Undoubtedly, this experience was the main antecedent of the institutionalization of the departmental structure.

During the decades of the twenties and thirties, the incorporation to university chairs of those university students pensioned by the JAE took place and they became the most outstanding scientists of Spanish science of the first third of the 20th century (Otero, 2014, p. 28). These new professionals helped to initiate some changes in university and in scientific work in critical need of them. A new university model was emerging, based on new foundations and references, which tried to leave behind the traditional Napoleonic model while trying to follow the German and Anglo-Saxon patterns. In fact, both models will be clear references in the frustrated project of the University Reform Act of 1933 promoted by Fernando de los Ríos (Gómez, 2009).

That modern draft Law of 1933 received a good general reception among the university professors and among men of culture. 
As stated by Puelles Benítez (2011, p. 68), "a good proof of its modernity is the triple conception of the University as a transmitter of wider culture, a trainer of higher level professionals and a research instructor, a mission that reminds us of the Ortega's famous conception of the University". But the dissolution of the Cortes in 1933 prevented it from being the subject of parliamentary debate.

A few years later, the Civil War stopped dead the consolidation of the Spanish scientific system. After the war, the university was left in a sorry state. On the one hand, the dramatic purge suffered by teachers and, on the other hand, the general lack of adequate scientific infrastructure, meant that this was not a significant element in the promotion of scientific research activities. Having overcome the autarchy phase, the option adopted by the technocratic strategy was oriented towards the modernization of Spain using as a source of inspiration foreign models - taking as a reference the German model (the German university reform of Humboldt, Schleiermacher and Fichte had made a great impact and received acceptance at European and world level) and Anglo-Saxon model. Against the model of a traditional university, focused on teaching and organization from chairs, the aim was to erect then a university capable of combining teaching and research, through the structure of the department that would arise a few years later.

Obviously, this reference model was introduced in a slow way and, probably, without taking into account the conditioning context of the moment. The technocrat project focused basically on incorporating science and technology as instruments of strategic value to achieve modernization and contribute to economic development. Undoubtedly, the influence of international organizations - UNESCO, OECD, etc. - was decisive for the insertion of the reference to science and technology as an item in the political agenda. Faced with the failure of the CSIC to fulfill its functions as the body responsible for national scientific policy, the reformist movement created in 1958 the Advisory Commission on Scientific and Technical Research (CAICYT), with the function of assuming the planning of scientific and technological policy (Sanz \& Lopez, 1997).

During the sixties, issues related to scientific research began to gain a presence in the political agenda, an aspect that would be reinforced especially after the exposition of problems and recommendations that an OECD report would make in 1963 on scientific research and technology in Spain. Even so, the course of $\mathrm{R} \& \mathrm{D}$ decision-making would remain extremely slow, and the measures adopted would be far from changing the existing scene.

Starting in 1970, again with the intervention of organizations such as UNESCO or the World Bank, and with the enactment of the LGE, a process of reform was initiated that, among other things, sought the professionalization of the teaching career and its indissoluble link with research work. The emergence of the concept of university autonomy was then linked not only to the departments - administrative centres, but also scientific ones - as the fastest and safest way to avoid the hindrance of one-person decisions, and to reduce the burden of bureaucratization (Hernández, 2008).

The effectiveness of the measures adopted at that time would only be appreciated in the course of time, especially after the establishment of democracy. However, it is essential to know the way in which these processes were initiated, to approach the origin in order to understand the subsequent evolution and its possible future projections. In the case of the departmental organization of the Spanish university we must go back to the mid-sixties, in order to locate the first formal attempts at institutionalizing the department as a fundamental part of the university network. A slow and late process if we compare it with other reference countries such as Germany, England or the United States.

At a normative level, the Law of July 17, 1965, promulgated under the presidency of Manuel Lora Tamayo in the Ministry of National Education (MEN) put the first stitch in an academic fabric that would still take some years to become truly effective. The next step would come with the enactment of the General Law on Education and Financing of the Educational Reform (LGE) of 1970, in which the department was considered part of the structure of the university, understood as a fundamental unit of teaching and research in related disciplines. In both laws we find the origin of the institutionalization of a new form of organization that would foster full development once the Law of University Reform (LRU) of 1983 and the Royal Decree 2360/1984 on university departments were implemented.

Despite the importance, in our humble opinion, this incipient transformation of the Spanish university has and the succession of decisions, events, initial problems and natural resistance to change which took place until the correct mechanism of the departments as independent administrative "nuclei" in charge of the management of university teaching and research, the attention of historians towards this phenomenon has been virtually nil until now. Once this lack of interest is verified within the field of historical-educational research, which contrasts with a significant number of articles and papers on departmentalized universities both in Latin America and the United States (see: Clark, 1971, 1976, 1977, 1993; Dressel, 1970; Dressel \& Reichard, 1970; Duryea, 2000; Machuca \& Becerril, 2000; Meneses, 1971; Smith \& Bender, 2007; Zamanillo, 1980), the following paper has as is key aim and objective to shed light on some basic aspects in relation to the regulations, motivations and decisions adopted during the 1960s with the purpose of introducing the departmental units.

\subsection{Material and methods}

For the elaboration of this study a methodology of historical-educational character has been used, supported by primary sources that have allowed the reconstruction of events and explanation of their development, the search for reasoned arguments and, ultimately, rearming the gestational history of the department in our universities. Among them the printed sources of unpublished character stand out, located for the most part in the Historical Archive of the University of Salamanca (hereinafter AUSA). As fundamental sources, it is worth pointing out the minutes and papers, sessions and documentation of the Council of Rectors, as well as the official communication and the personal correspondence of the Rector of the University of Salamanca with those responsible for different authorities (official bodies, MEN and MEC, general director of university education (EU), etc.). We may add the minutes of the sessions of faculty meetings, a magnificent instrument for the study of authentic and corporate university life.

As a complement to the checking of these strictly documentary and archive material, direct reference has been made to legislative sources (laws, orders, decrees, etc.), through which it is possible to compare the various approved norms and guidelines. Likewise, the press has been used (newspaper El Adelanto), considering that it constitutes a versatile source of enormous utility for research.

All the documentation collected has been subjected to internal and external criticism to verify its validity and veracity and has been contrasted with bibliographical references that have allowed the progressive construction of the discourse. 


\section{DISCUSION: TOWARDS A NEW DEPARTMENTALIZED STRUCTURE OF THE SPANISH UNIVERSITY}

The appearance of the department concept as a new structural model for the organization of faculties turned out to be one of those changes linked to the attempt to improve the Spanish university during the sixties. It emerged as an administrative unit, within which various chairs would be grouped; chairs which, it was understood, had similar teaching and research interests. That is, the fundamental aim was to turn the page on the system of chairs, the traditional form of operational control in most European and Latin American universities - going back to the original medieval university - (Clark, 1983) and based on the personal and omnipotent figure of the professor, in order to make the leap towards a model of horizontal leadership that is typical of a more democratic conception of management (Zabalza, 2000).

The idea of the department was introduced with the intention of inserting research as an eminently university task. The frequent problems of teacher absenteeism, the scarce dedication or the exclusivity of the teaching tasks against the abandonment of the researching ones forced the taking of decisions and the change of the governmental dictates.

However, this type of organization, now fully incorporated into universities and accepted as something inherent to them - although its running revealed itself as deficient in some cases, questionable in others (Doyle \& Brady, 2018) and, there have even been phenomena of fusion of departments motivated basically by the situation of economic crisis in recent years - would be accepted reluctantly by the different heads of chairs. That novelty would lead to conflicts and a long and slow process of full approval.

For Clark (1983), quoted by Mainero (2004, p. 49), certain specific structures of higher education, such as the department, contribute to unifying the disciplines, thus granting coherence to these organizing bearers of the academic subjects and of the "knowledge nuclei" they contain. The problem is that, at that time, for most of those responsible for chairs that unification did not generate great expectations.

In Spain, the first echoes of the new departmental organization began to be heard during the year 1963. At that time, the preliminary plan for the organization and restructuring of the university teaching staff began to take shape at ministerial level. It was presented to the Council of Rectors, where the figure of the senior lecturer was widely discussed in successive sessions (González, 2015). The project ${ }^{1}$ was sent confidentially and with reserved character to the different universities so that they proceeded to its study, debate and subsequent allegation of suggestions. Therefore, at first, the opinion and initial assessments of the different boards of faculty seemed to be taken into account.

That preliminary draft already contained the idea of creating the university departments, although in an abstract and undefined way. In fact, the title that it was given was simply the restructuring of university staff and the concept of reordering university faculties did not appear, as it definitely would with the passing of the law. Basically, in relation to the departments, emphasis was placed on the concept of "unity", on the understanding that this new structure would have its own entity and would be considered as such for purposes of consignments, subsidies, etc.

In the session of the Council of Rectors of May 25, 1963, the Rector of the University of Valladolid, Hipólito Durán Sacristán, stated his objections to the draft bill, unanimously expressed

1 AUSA, copy of the project on the fundamental rules for the restructur-ing of teaching staff, AC 10204/11, pp. 334-336. by the professors of that centre. He highlighted the problem of elimination of the chairs. The General Director of the EU, Juan Martínez Moreno, clarified the following:

It is not about reducing the number of chairs, since what will be done is to group them in a superior unit, the Department, so that they are better equipped. (...) It is a question of separating the concept of professor from the concept of Chair, making it clear that the current professors will not be deprived of any of the rights they have gained (AUSA, Minutes of the Council of Rectors held on May 25th, 1963, AC 3275/11).

The General Director himself said, what the Ministry intended was the expansion of the number of professors, to the extent imposed by the teaching needs, without this implying an increase in the number of chairs. The MEN found in that departmental organization a new channel for the necessary adaptation of the university to the Spanish contextual circumstances however the professors expressed their fear of losing the bastion into which they had converted their chairs. At this point we must consider a key aspect for the understanding of the deep reluctance of the professors of that time to the new type of organization: the traditional professional performance, focused almost exclusively on teaching, and the construction of an identity as a university professor (Sánchez-Claros, 2014), understood as the set of beliefs, attitudes and expectations of the lecturer about teaching and his own role as an exclusive owner of his chair.

For this and other reasons, the significant modifications in the university structure would bring with it the reservations and even the direct opposition of a significant number of professors during successive years. An example of this is the statement issued by the Faculty of Medicine Board of the University of Salamanca in April $1965^{2}$, only two and a half months before the new legislation came into effect. Through it they expressed their surprise at verifying that the draft of the project had not taken into account "the numerous observations and suggestions made in different Boards of Faculties, raised by many professors in private and, especially approved by a large majority in the Assembly of Medicine Professors, held in October in Seville and elevated on that occasion to the Superiority"3. They considered that modifications of that character should not and could not be made without taking into account the general criteria of those who were an essential part of the university.

Regarding the new departmental organization, the indicated text mentioned above added:

The University accepts and wishes the constitution of departments through a process of extension of the current Chair, giving access to facilities and personnel essential for effective teaching and research. It is inadmissible, on the other hand, the intention of the Bill to create Departments through the opposite process: the absorption of "related" Chairs, thus reducing the number of functional units. This supposes an involutive phenomenon rather than the essential evolution and development ${ }^{4}$.

2 AUSA, Document of the Board of the Medicine Faculty (hereinafter JF, abbr. for "Junta de Facultad") regarding the bill about the structure of Universities and teaching staff of April 10th, 1965, AC 3059. Sent from the Rectors' office of the University of Salamanca to the General Director of EU on April 22nd, 1962, in AUSA, AC 10207/1, pp. 40-41.

3 Ibid.

4 Ibid. 
Therefore, the idea of the department was welcome, provided that structure did not bring with it the disappearance of chairs. Basically, the idea did not quite appeal to the main part of the teaching staff, in the light of the considerations that, as an example, will be pointed out in the text, but a positive attitude was shown to its consideration, maintaining some basic premises for the conservation of the personal bastions. This is the point at which one of the fundamental questions arises which is reflected in the study of all the documents that show this process: the fear of losing the trenches into which the unipersonal chairs had turned. The Medicine professors, in the referred letter, came to label the proposal as a contradiction in terms to face the increase of the students.

In theory, the motivation for the creation of the departments generated an absolutely opposing idea to that argument. According to Zabalza (2000, p. 48), the departments "could constitute a more friendly and positive system for lecturers. They opened the possibility of establishing stronger and more productive lines of research, (...) of developing more coordinated teaching, (...) that new teachers felt more protected (...), etc.”. However, a significant part of the faculty did not seem to see it that way. Most of them considered that an important point was still being ignored: the real situation of shortage at the university in terms of facilities and buildings, aspects that demanded an "urgent and radical renewal, much more necessary and urgent than planning new structuring, ignoring that any lack of effectiveness in the old one is not at all due to its imperfection, but to its lack of personnel, space and resources"

In fact, the truth is that this lack of contact between lectures, this idea of the cohesive and harmonious department and that ignorance towards what other colleagues do in their classrooms or in their research, formed and continues to be part of one of the basic problems of our universities (Fernández-Soria, 2013), and it was undoubtedly one of the bases of the problem in the acceptance of the new departmental structure.

Even so, not all positions were opposed to the new proposal of departmental organization. An example of this is the position held by Fernando Lázaro Carreter, who argued, in statements to the press, that the practical results this new organization would be, among others, a "better professional training, through departments that will replace the current sections, whose structure is very deficient" (El Adelanto, March 10, 1963).

Finally, on July 17, 1965, the Law was passed and with it, the departments appeared, somewhat more defined now. A new organizational model that was specified as a university structural unit, whose purpose would be to group people and material resources for teaching, training and research in the field of a discipline or related disciplines. Until then, the Spanish university presented an organizational scheme that revolved around the chair, where practically everything began and ended. The professors were the main support of the model of the Francoist university and the rest of the teaching staff was located far below in the current pyramid scheme. That is, in a university there were faculties, within them there could be different sections, and the ordering of them was carried out through the chairs. Associated with them could be seminars, laboratories, etc. Interestingly enough, this last type of structure which were situated at the lower level, in most cases, became the best channels for university training and research, and symbolically represented, small cracks in the wall round the vantage point the chairs, insufficiently equipped, had turned into.

5 AUSA, Document of JF of Medicine regarding the bill about the structure of Universities and its teaching staff of April 10th, 1965, AC 3059 .
The rigid centralism to which the university was subjected had generated important problems and showed increasing inefficiency, especially when the number of students entering higher education had started an exponential growth that did not keep up pace with an increase in resources. The necessary adaptation of spaces and resources or the significant increase of teaching staff were issues that the government was aware of and tried, at least that was what it said, to face in an efficient manner.

At this point, the idea drawing the faculty together around the department started to grow. The department would have, according to the legislation, the following functions: a) Coordinate the teachings of the disciplines that comprise it; b) Launch projects and research as a team, without diminishing the freedom and initiative of personal work by the Professors; c) Promote the scientific and teaching development of the chairs involved, facilitating their work and the obtaining and distribution of resources; d) Serve as a link between the chairs and the authorities of the faculty or the different sections.

Therefore, within a department several chairs would be grouped that should work harmoniously to ensure that the teaching and research work that was developed within it was fruitful. That is to say, from now on the withdrawal of the isolated chair was seen as the only solution to the problem, since, due to its structure and multiplication, in some cases, caused disintegration and lack of coordination (Martínez, 2005). They should come together to form the department, a larger and varied group that would have greater power and could cope, in better conditions, with the new educational circumstances. But how to make that step while maintaining a mentality such as that denounced in his writings by Antonio Tovar Llorente?:

The mentality of "professor proprietor" of his chair, combined with the bureaucratic inflexibility and the lack of habit of planning rational things that are in our hands to perform, accustomed to every measure of academic organization falling from the sublime heights, is a very serious hindrance, especially where the privileged academic situation is highly valued in the lucrative exercise of the profession (Tovar, 1968, p. 26).

For the first time, a meeting was called, within the university faculty; this meeting would be attended by a broad group of professors that would integrate the staff of the department: ordinary and extraordinary professors, senior lecturers, lecturers, practical's assistants, research personnel, foreign languages assistants, laboratory directors and auxiliary and subordinate personnel. All of them were represented by a head of department, with the category of professor, and chosen by the Rector at the suggestion of the department itself. Likewise, the clinics, seminars or libraries of each chair would be incorporated into the department.

Regardless of formal aspects, at that time, the main question was whether the chairs would cease to be those structures that served as a parapet for those in charge of the tasks or, on the contrary, if the implementation of this new organizational model would have to face the distrust of the teaching body and, finally, it would be inefficient because there was no successful adaptation. That generalized mentality among the professors of Francoism, which also Tovar correctly defined, resulted "sometimes in not discovering the sources from which you can learn and acting in teaching the same way as in other aspects of our society: excel by keeping down others, instead of triumphing in a general ascent of all implied, supported by the success of collaborators and colleagues" (Tovar, 1968, p. 26). 
If the departments did not become cohesive entities (Bitziers, Sleegers, \& Imants, 1999, p. 296), no positive results would be obtained. The professors of similar areas had to learn to collaborate and work together, but obviously the change of mentality that it demanded would not occur immediately. Numerous teachers were accustomed to individual work and the qualitative leap that took place when work teams were formed required a series of values of camaraderie, solidarity, respect, etc. that only those could encourage. In essence, there was a lack of awareness of the excellent results that this system could produce and, therefore, it is not strange that this new organizational model generated doubts, contradictions and disagreements among the group of professors. The truth is that its implementation would take place very slowly and the issues to be debated around this issue, centralized in the commissions that were created to prepare the organizing decrees of the faculties, multiplied after the enactment of the Law.

Finally, on March 31, 1966, the first two decrees on how departments should be organized were published for the faculties of Sciences, with 25 departments, and Arts, with 29. In both cases, the possibility of merging several of the departments into one was contemplated, or of subdivision of any of them. Likewise, the possibility of the advisable creation of other departments (such as Mathematics, Physics, Geology or Biology) was considered in the faculties that did not have those sections.

Between these two decrees and the regulating decrees of the Faculties of Medicine and Law more than one year elapsed. In the case of the first faculty, the regulations were approved on June 1, 1967 and contemplated the existence of a total of 11. The small number of departments of Medicine, compared to the number of the previous ones, is evident. There is a clear disproportion, even taking into account the existence of sections. Most of the medical departments included a very large number of specialties; for example, the Department of Internal Medicine had Digestive, Circulatory, Respiratory, Neurology, Nephrology, Infections, Nutrition, Hematology, Endocrinology, Locomotive Apparatus, Geriatrics and other related departments.

Consequently, the ordering of Medicine turned out to be the most problematic, an aspect that can be supported, for example, by the study of some documents issued by the Deanship of the Faculty of Medicine of the University of Salamanca. The departmental organization did not convince its professors and they expressed this on several occasions. The reference to a letter dated June $10,1966^{6}$, one year before the decree was passed, is almost obligatory since it clearly reflects the argument presented. The $\mathrm{JF}$, having received the text prepared for the restructuring of the Faculties of Medicine, presented ten consensual considerations in relation to this.

These considerations reflected, for example, that the rearrangement or subordinations of various chairs or fractions of chairs in a small number of departments showed that the Commission in charge of the project had not been duly informed about the concept, sources, methods, content, etc. of some specialties; they also noted that with this proposal they were "hypertrophying the department and exaggerating its role" and that it was an "involutive position" to suppress the autonomy of specialties, begun in 1850 and with full development in 1902, as a result "not of artificial laws, as the project that we analyze, but of a natural process of advance in the complexity of the scientific knowledge".

6 AUSA, Agreement of the JF of Medicine regarding the project of departmental structuring of the Medicine Faculties, June 10th, 1966, AC 3059 .
The Medicine faculty of Salamanca described the new normative framework as "artificial legislation" and considered that this whole process did not benefit neither the research and education nor the assistance of the patients, nor the economy of the university. Consequently, in Medicine they requested the creation of departments from a single chair, by extension and development of the same. In addition, they threatened with non-assignment to any of the projected departments, if the project was carried out.

A year later, opposition to this type of organization continued to be expressed. Professor Luis Zamorano reiterated his idea that the organization in departments did not solve any of the problems of the Spanish university and characterized it as an "organization devised in the Ministry of Education with no knowledge of university problems"?

The majority of Medicine professors in Salamanca did not find an adequate system in the departmental organization, but the truth is that they were afraid that their refusal could hinder the allocation of credits for the development of the center's services. Faced with this situation, the opinions of some professors are strange, as is the case of Rafael Bartolozzi, who claimed the following: "if they want us to become pagans of this maneuver, I personally prefer to fight against the constitution of the department, even if the chair continues in the present state of current economic misery". Professor Sanchez Granjel and Luis Zamorano immediately backed this argument.

The issue of the departmental organization was closed in that session with the statement of the Dean, who informed those present of the situation of the University of Valladolid that had already agreed to form departments. However, that information did not encourage the Salamanca professors who, finally, decided to transmit their determined opposition to the Superiority. However, a little more than a year later, the assistants to the new session of JF were already favorable to the constitution of the departments "because it can bring advantages with the centralization of some services and improvements in the endowments of personnel and material"".

In summary, in Medicine the process of transformation from chairs to departments turned out to be very complex, since most of the departments that were suggested to be constituted were composed of a very large number of chairs. However, in Law we find exactly the opposite, where the composition of the department was made, in most cases, from a single chair, two at the most. Therefore, at first the resistance was minimal since, in essence, the chair acquired the name of department, but in the power and way of operating little or nothing varied. But the case of these faculties is more complex in its approach, if we take into account the publications that delve into this process of transformation (Martínez, 2005, 2017).

\section{CONCLUSIONS}

In the mid-sixties a new university structure was drawn up, based on departmental units, in order to achieve a better coordination of the teachings, an optimal and more adequate distribution of the means of work and, basically, progress accelerated in terms of university research. However, as a result of the rigid centralism, the lecturers were not really involved in this process of change and, consequently showed certain initial reservations.

\footnotetext{
7 Faculty of Medicine of Salamanca Archives (hereinafter AFM), meet-ing held on July 6th, 1966, p. 170.

8 Ibid.
} 
The department offered the faculty the possibility of starting up a new work system based on group work. The relationship between chairs could generate interesting benefits at teaching and research level, however, the great change with respect to the model of organization that had been established in the Francoist university alarmed lecturers. The problem seemed to arise mainly from the concretion of the great fields of study, those that would define the name of each of the departments. But, as we have seen, the real background of the issue was really coloured by the fear of the loss of power or the ability to act and by the demand for a change in the identity of the role of the university professor, now integrated into a group of lecturers of different categories.

After all the previous analysis, we are now in a position to be able to underline the most distinctive differences of the basic operating units of the university: the chair and the departments. In summary, and after all that has been analysed, the chair basically concentrated the responsibilities of the academic unit in one person, the professor. In contrast, the department proposed distributing responsibilities and power among several teachers of similar higher rank and admitted greater participation of associate and assistant professors. It became, therefore, the foundation of both the collegiate order and the bureaucratic order at the operational level (Clark, 1983). But the actual transition from one to the other structure would not occur effectively during the period studied. The substantial modification that was intended to be introduced at that time, was reflected only in the normative plan, but not so much in real university life. The first regulating decrees of the departments began to appear, but the effective leap for their adaptation and implementation would require the passage of time, necessarily undergoing both a change in the university model and a change of mentality of the body of professors.

In this case, some basic sociological questions are interwoven with respect to the interaction of groups of professionals and/or intellectuals: the internal structure of academic power, the political conditioning factors of academic and scientific life and the relationship between these fields and that of economic production. In the transition from chairs to departments, from our perspective, these aspects have special relevance and explain the slow process of change.

Therefore, what we have seen in this paper is only the first phase of discussion of a model and its introduction at the normative level, and not so much the actual implementation of it. Initially, in the faculties there was a kind of rearrangement of the chair into a higher unit, but that, at that time, had no major consequences or wide scope. A new advance would take place with the adoption of the 1970 LGE and, years later, with the enactment of the 1983 LRU, considered as the formal registration of death of the old university model, with which the department would achieve a powerful impetus and it would be consolidated as a basic structure in the functioning of the university, capable of quickly responding to the requirements and demands of society, science and education.

\section{REFERENCES}

Carrillo-Linares, A. (2015). Universidades y transiciones políticas: el caso español en los años 60-70. Espacio, Tiempo y Educación, 2(2), 49-75. doi:10.14516/ ete. 2015.002 .002 .004

Clark, B. (1983a). The higher education system. Academic organization in cross national perspective. California: University of California Press.

Clark, B. (1983b). Faculty organization and authority. En V. Baldridge (Comp.), Academic gobernance. Berkeley, California: McCutchan.

Doyle, T., \& Brady, M. (2018). Reframing the university as an emergent organization: implications for strategic management and leadership in higher. Journal of Higher Education Policy and Management, 40(2), 1-16.
Dressel, P. L. (1970). The confidence crisis: An analysis of university departments. San Francisco: Jossey-Bass.

Dressel, P. L., \& Reichard (1970). The university department: Retrospect and prospect. The Journal of Higher Education, 41 (5), 387-396. doi:10.2307/1977391

Fernández, J. M. (2013). Problems and challenges for the politics of education before the change of prominence experienced by educational actors. Journal of New Approaches in Educational Research, 2(2), 67-65. doi:10.7821/naer.2.2.63-71

Gómez, T. F. (2009). La universidad alemana, una referencia para el Proyecto de Ley de Reforma Universitaria de 1933. En J. Mª Hernández (Dir.), Influencias alemanas en la educación española e iberoamericana (1809-2009) (pp. 79-90). Salamanca: Globalia Ediciones Anthema.

Hernández, E. (2008). Tres décadas de Educación Superior en España: universidades e investigación. Cuadernos del Instituto Antonio de Nebrija, 11(1), 101-134.

Machuca, V. M., \& Becerril, S. (1993). La departamentalización en las instituciones de educación superior. Una experiencia en proceso. Revista de Educación Superior: ANUIES, 22, 1-6.

Mainero, N. E. (2004). Características distintas de las comunidades académicas en la educación superior: bases teóricas para analizar sus incidencias en las valoraciones acerca de la calidad y de la igualdad educativa. Fundamentos en Humanidades, V(1), 45-61.

Malagón, L. A. (2005). Cambios y conflictos en los discursos político-pedagógicos sobre la universidad. Archivos Analiticos de Políticas Educativas, 13(22), $1-21$.

Martín, A. (1998). La departamentalización. Contexto y concepto. Sinéctica, Revista Electrónica de Educación, 12. Retrieved from http://www.redalyc.org/articulo.oa?id=99826006011

Martínez, M. (2005). La Facultad de Derecho en los años sesenta. Creación de departamentos y nuevos planes de estudios. Cuadernos del Instituto Antonio de Nebrija de Estudios sobre la Universidad, 8, 117-178.

Martínez, M. (2017). Las facultades de derecho entre la crisis del modelo liberal de universidad y la del 68. En A. Martínez, \& C. Prados (Ed.), Las universidades durante el proceso de democratización española (1968-1983): una perspectiva jurídica (pp. 129-143). Madrid: Dykinson, S.L.

Meneses, E. (1971). La organización departamental en las universidades. Revista del Centro de Estudios Educativos, 1(3), 75-78.

Ministerio de Educación y Cultura. Decreto 1243/1967, de 1 de junio, sobre ordenación en Departamentos de las Facultades de Medicina, BOE n ${ }^{\circ} 145$ de 19 de junio de 1967.

Ministerio de Educación y Cultura. Real Decreto 2360/1984, de 12 de diciembre, sobre departamentos universitarios, BOE, $\mathrm{n}^{\circ} 12$ de 14 de enero de 1985. MEC. Ley 14/1970, de 6 de agosto, General de Educación y Financiamiento de la Reforma Educativa, BOE, n. ${ }^{\circ} 187$ de 6 de agosto de 1970.

Ministerio de Educación y Cultura. Ley Orgánica 11/1983, de 25 de agosto, de Reforma Universitaria, BOE, n. ${ }^{\circ} 209$ de 9 de septiembre de 1983.

Ministerio de Educación Nacional. Ley 83/1965, de 17 de julio, sobre estructura de las Facultades Universitarias y su Profesorado, BOE, n. ${ }^{\circ} 173$ de 21 de julio de 1965.

Ministerio de Educación Nacional. Decreto 1199/1966, de 31 de marzo, sobre ordenación de Departamentos en las Facultades de Ciencias, BOE n. ${ }^{\circ} 116$ de 16 de mayo de 1966.

Ministerio de Educación Nacional. Decreto 1200/1966, de 31 de marzo, sobre ordenación de Departamentos en las Facultades de Filosofía y Letras, BOE n. ${ }^{\circ} 116$ de 16 de mayo de 1966.

Muñoz, E. (2001). Politica cientifica (y tecnológica) en España: Un siglo de intenciones. Ciencia al día internacional, 4(1). Retrieved from http://www.ciencia. $\mathrm{cl} /$ CienciaAlDia/volumen4/numero1/articulos/articulo2.html

Otero, L. E. (Dir.). (2014). La universidad nacional-católica. La reacción antimoderna. Madrid: Dykinson.

Otero, L. E. (Dir.). (2006). La destrucción de la ciencia en España. Depuración universitaria en el franquismo. Madrid: Editorial Complutense.

Puelles, M. de (2011). Política y educación en la España contemporánea. Madrid: Universidad Nacional de Educación a Distancia.

Sánchez-Claros, J. P. (2014). Influencia de la cultura académica de origen en el desempeño docente de profesores universitarios noveles. Historia y Comunicación Social, 19, 523-533. doi:10.5209/rev_HICS.2014.v19.45046

Sanz, L. (1997). Estado, ciencia y tecnología en España: 1939-1997. Madrid: Alianza.

Sanz, L., \& López, S. (1997). Política tecnológica versus política científica durante el franquismo. Quaderns d'Història de l'Enginyeria, 2, 77-118.

Smith, W., \& Bender, T. (2007). American higher education transformed, 19402005: Documenting the national discourse. United States: The Johns Hopkins University Press.

Tovar, A. (1968). Universidad y educación de masas (ensayo sobre el porvenir de España). Barcelona: Ediciones Ariel.

Wittrock, B. (1996). Las tres transformaciones de la Universidad Moderna. En S. Rothblatt, \& B. Wittrock (Eds.), La universidad europea y americana desde 1800 (pp. 331-397). Barcelona: Pomares-Corredor. 
Witziers, B., Sleegers, P. J. C., \& Imants, J. G. M. (1999). Departments as teams: functioning, variations and alternatives. School Leadership Management, 19(3), 293-304. doi:10.1080/13632439969050

Zabalza, M. (2000). El papel de los departamentos universitarios en la mejora de la calidad de la docencia. Revista Interuniversitaria de Formación del Profesorado, 38, 47-66.

Zamanillo, E. (1980). La organización departamental en las instituciones de Educación Superior. Revista de Educación Superior: ANUIES, IX(3-35), 1-6.

How to cite this article: González Gómez, S. (2019). The Process of Change from Chairs to Departments at Spanish Universities. Journal of New Approaches in Educational Research, 8(1), 66-72. doi:10.7821/ naer.2019.1.364 